\title{
PENGARUH PAJAK DAERAH DAN RETRIBUSI DAERAH TERHADAP BELANJA MODAL PEMERINTAH DAERAH KOTA LUBUKLINGGAU
}

\author{
${ }^{1}$ Subianto, ${ }^{2}$ Ferry Yusrizal Sipahutar \\ ${ }^{1,2}$ Prodi Akuntansi, Fakultas Ekonomi, Universitas Musi Rawas \\ E-mail : ${ }^{1}$ subiantobae@gmail.com, ${ }^{2}$ ferryyusrizal135@gmail.com
}

\begin{abstract}
ABSTRACK
The era of decentralization and regional autonomy is a challenge for every region to take advantage of opportunities in exploring regional potential. Efforts to increase local revenue $(P A D)$ can be done by increasing the effectiveness of receiving retribution from PAD sources, especially local fees. This study aims to determine and analyze the contribution of funeral service permit fees to the local revenue of Palembang City in 2015-2019. The collection of user fees has been regulated in Regional Regulation Number 12 of 2015 concerning charges for funeral services and asylum which is a basic reference for maximizing administrative services managed by Ilir Barat Satu Sub-district, Palembang City. This research uses descriptive quantitative analysis method. The data collection technique is done by using secondary data through documentation techniques. The data used is a funeral service permit retribution. The analysis method used is contribution analysis, which is an analytical tool used to determine how much the contribution of levies is to local revenue. The result of the research is that the contribution value of funeral service permit fees shows a tendency to fluctuate each year. The average percentage contribution of receiving funeral service permit fees with good enough criteria reaches $20.17 \%$ which means it contributes to the Regional Original Income of Palembang city.
\end{abstract}

Keywords : Competence, Supervision, Work Productivity

\section{ABSTRAK}

Rumusan masalah dalam penelitian ini adalah bagaimana pengaruh Pajak Daerah dan Retribusi Daerah terhadap Belanja Modal baik secara parsial dan simultan pada Pemerintah Daerah Kota Lubuklinggau. Penelitian ini termasuk Penelitian Kuantitatif. Terdiri dari tiga variabel dalam penelitian yang secara keseluruhan dikembangkan menjadi 20 indikator. Hipotesis dalam penelitian ini digunakan untuk mengetahui bagaimana pengaruh dari masing-masing variabel tersebut. Teknik analisis yang digunakan dalam penelitian ini ini berupa Analisis Regresi Linier Berganda. Hasil analisis persamaan Regresi Linier Berganda diperoleh nilai $\mathrm{Y}=145019912,126+1,709 \mathrm{X}_{1}+6,088 \mathrm{X}_{2}$. Sedangkan untuk uji t hasil analisis menunjukan hasil bahwa Pajak Daerah tidak berpengaruh terhadap Belanja Modal. Dari analisis Retribusi Daerah terhadap Belanja Modal menunjukan hasil bahwa tidak berpengaruh terhadap Belanja Modal. Berdasarkan hasil uji $\mathrm{F}$ diatas diperoleh $\mathrm{F}$ hitung $<\mathrm{F}$ tabel yaitu $1.045<4.74$ dengan nilai signifikansi sebesar 0,401>0,05, sehingga dapat disimpulkan bahwa tidak ada pengeruh Pajak Daerah dan Retribusi Daerah terhadap Belanja Modal. Berdasarkan Uji Koefesien Determinasi diketahui bahwa nilai dari koefesien determinasi ( $R$-Square) pada penelitian ini adalah sebesar 0,230 atau 23\% dengan demikian kemampuan variabel independen yang terdiri dari Pajak Daerah dan retribusi Daerah dapat menjelaskan variabel dependen Belanja Modal sebesar 23\%, sedangkan sisanya sebesar 73\% dijelaskan oleh variabel lain di luar penelitian ini.

Kata kunci : Pajak Daerah, Retribusi Daerah, Belanja Modal 


\section{PENDAHULUAN}

Pelaksanaan otonomi daerah memberikan kewenangan kepada daerah untuk mengatur dan mengelola daerah masing-masing sebagai administrator penuh, masing-masing daerah harus bertindak efektif dan efesien agar pengelolaan daerahnya lebih terfokus dan mencapai sasaran yang telah ditentukan. UndangUndang Nomor 23 tahun 2014 tentang Pemerintah Daerah dan Undang-Undang Nomor 33 tahun 2004 tentang Perimbangan Keuangan antara Pemerintah Pusat dan Pemerintah Daerah merupakan landasan yang mengatur tentang otonomi daerah dan desentralisasi fiskal. Kedua Undang-Undang dibidang otonomi tersebut berdampak pada terjadinya pelimpahan kewenangan yang semakin luas kepada pemerintah daerah dalam rangka meingkatkan efektivitas dan efesiensi penyelengara fungsi pemerintah daerah.

Menurut Undang - Undang Nomor 23 tahun 2014 untuk merealisasikan pelaksanaan Otonomi Daerah maka sumber pembiayaan pemerintah daerah tergantung pada peranan Pendapatan Asli Daerah (PAD). Pendapatan Asli Daerah adalah sebagai salah satu penerimaan daerah mempunyai peranan penting dalam pembangunan. Hal ini dapat dilihat dalam pelaksanaan Otonomi Daerah dimana peranan PAD diharapkan dan diupayakan dapat menjadi penyangga utama dalam membiayai kegiatan pembangunan di daerah. Oleh karena itu daerah harus dapat mengupayakan peningkatan penerimaan yang berasal dari daerah sendiri. Dengan demikian akan memperbesar tersedianya keuangan daerah yang dapat digunakan untuk berbagai kegiatan pembangunan yang bersifat mandiri

Menurut Undang-Undang Nomor 23

Tahun 2014 Pendapatan Asli Darah itu sendiri terdiri dari 4 komponen yaitu : Pajak daerah, Retribusi daerah, hasil pengelohan kekayaan daerah yang dipisahkan, dan lainlain pendapatan daerah yang sah.
Menurut Peraturan Kementerian Keuangan 127/ PMK, 02/2015 belanja modal adalah pengeluaran untuk pembayaran perolehan aset tetap dan/atau aset lainnya untuk menambah nilai aset tetap dan/atau aset lainnya yang memberi manfaat lebih dari satu periode akuntansi.

Pembelanjaan daerah tidak terlepas dari pendapatan daerah yang diterima. Permendagri Nomor 33 tahun 2019 menjelaskan bahwa belanja modal merupakan klasifikasi dari belanja daerah, dimana sumber-sumber yang mempengaruhi Belanja Modal adalah besar kecilnya pendapatan daerah yang diterima oleh daerah.

Pada tahun 2003 Kota Lubuklinggau terbentuk setelah terjadi nya pemekaran dari Kabupaten Musi Rawas, setelah itu kota Lubuklinggau terus berusaha dalam melakukan peningkatan penerimaan daerah khususnya dalam bidang Pajak Daerah dan Retribusi Daerah, Pajak Daerah dan Retribusi merupakan pendapatan terbesar di kota lubuklingau. Setelah itu kota Lubuklinggau terus melengakapi kebutuhan untuk melakukan kegiatan operasional pemerintahannya demi untuk menciptakan layanan publik kepada masyarakat dan melakukan pembangunan dan penciptaan infrastruktur demi menambah pendapatan daerah dalam sektor Pajak Daerah dan Retribusi Daerahnya guna dapat menciptakan kemandirian bagi daerahnya sendiri.

Dengan demikian penulis ingin melakukan penelitian unntuk mengetahui seberapa besar kontribusi pengaruh pajak daerah dan retribusi daerah dan juga untuk mengetahui seberapa besar kontribusi masyarakat kota Lubuklinggau dalam membiayai belanja modal kota lubuklinggau dalam hal pembangunan infrastruktur, kegiatan operasional dan pelayanan publik kepada masyarakat. 


\section{TINJAUAN PUSTAKA}

\subsection{Pajak Daerah}

\section{Definisi Pajak Daerah}

Menurut Marihot (2010:7) pajak daerah adalah pungutan dari masyarakat oleh negara (pemerintah) berdasarkan undangundang yang bersifat dapat dipaksakan dan tertuang oleh yang wajib membayarnya dengan tidak mendapat prestasi kembali (kontra prestasi/balas jasa) secara langsung, yang hasilnya digunakan untuk membiayai pengeluaran negara dalam penyelengaraan pemerintahan dan pembangunan.

Menurut undang-undang No 28 Tahun 2009 pajak daerah adalah kontribusi wajib kepada daerah yang tertuang oleh orang pribadi atau badan yang bersifat memaksa berdasarakan undang-undang, dengan tidak mendapatkan imbalan secara langsung dan digunakan untuk keperluan daerah bagi sebesar-besarnya kemakmuran rakyat.

\section{Jenis Pajak Daerah}

Berdasarkan Undang-Undang No 28 Tahun 2009 pajak daerah di indonesia dibagi menjadi dua jenis yaitu, Pajak Provinsi dan Pajak Kabupaten/Kota. Pembagian ini dilakukan berdasarkan sesuai dengan kewenangan pengenaan dan pemungutan masing-masing daerah pada wilayah administrasi provinsi atau kabupaten/kota yang bersangkutan. Dan berdasarkan Undang-Undang No 28 Tahun 2009 ditetapkan enam belas pajak daerah, yaitu 5 pajak provinsi dan 11 pajak kabupaten/kota.

\section{Tabel 1}

PAJAK PROVINSI DAN PAJAK KABUPATEN

\begin{tabular}{|c|c|}
\hline Pajak Provinsi & Pajak Kabu \\
\hline $\begin{array}{l}\text { 1. Pajak Kendaraan } \\
\text { Bermotor } \\
\text { 2. Bea Balik Nama } \\
\text { Kendaraan } \\
\text { bermotor } \\
\text { 3. Pajak Bahan } \\
\text { Bakar Kendaraan } \\
\text { Bermotor } \\
\text { 4. Pajak Air } \\
\text { Permukaan } \\
\text { 5. Pajak Rokok }\end{array}$ & $\begin{array}{l}\text { 1. Pajak Hotel } \\
\text { 2. Pajak Restoran } \\
\text { 3. Pajak Hiburan } \\
\text { 4. Pajak Reklame } \\
\text { 5. Pajak Penerangan } \\
\text { Jalan } \\
\text { 6. Pajak Mineral Bukan } \\
\text { Logam dan Batuan } \\
\text { 7. Pajak Parkir } \\
\text { 8. Pajak Air Tanah } \\
\text { 9. Pajak Sarang Burung } \\
\text { Walet } \\
\text { 10. Pajak Bumi dan } \\
\text { Bangunan Perdesaan } \\
\text { dan Perkotaan } \\
\text { 11. Bea Perolehan Hak } \\
\text { Atas Tanah dan } \\
\text { Bangunan }\end{array}$ \\
\hline
\end{tabular}

Sumber : Undang-Undang Nomor 28 Tahun 2009

\section{Objek Pajak Daerah Kabupaten/Kota}

Menurut Undang-Undang Nomor 29

Tahun 2009 yang menjadi objek pajak yaitu:

a. Objek Pajak Hotel

b. Objek Pajak Restoran

c. Objek Pajak Hiburan

d. Objek Pajak Reklame

e. Objek Pajak Penerangan Jalan (PPJ)

f. Objek Pajak Mineral Bukan Logam dan Bantuan

g. Objek Pajak Parkir

h. Objek Pajak Air Tanah

i. Objek Pajak Sarang Burung Walet

j. Objek Pajak PBB Perdesaan dan Perkotaan

k. Objek Pajak BPHTB

\section{Tarif Pajak Kabupaten/Kota}

Sesuai Undang-Undang Republik Indonesia Nomor 28 Tahun 2009, tarif pajak Kabupaten/Kota ditetapkan paling tinggi yaitu: 
Tabel 2

\section{TARIF PAJAK DAERAH}

KABUPATEN/KOTA

\begin{tabular}{|l|c|}
\hline \multicolumn{1}{|c|}{ Jenis Pajak } & Tarif Pajak (\%) \\
\hline Pajak Hotel & 10 \\
\hline Pajak Restoran & 10 \\
\hline Pajak Hiburan & 35 \\
\hline Pajak Reklame & 25 \\
\hline $\begin{array}{l}\text { Pajak Penerangan } \\
\text { Jalan }\end{array}$ & 10 \\
\hline $\begin{array}{l}\text { Pajak Mineral Bukan } \\
\text { Logam dan Batuan }\end{array}$ & 25 \\
\hline Pajak Parkir & 30 \\
\hline Pajak Air Tanah & 20 \\
\hline $\begin{array}{l}\text { Pajak Burung Sarang } \\
\text { Walet }\end{array}$ & 10 \\
\hline $\begin{array}{l}\text { Pajak PBB Perdesaan } \\
\text { Dan Perkotaan }\end{array}$ & 0,3 \\
\hline \multicolumn{2}{|c|}{ Objek Pajak BPHTB } \\
Sumber : Undang-Undang Nomor 28 Tahun 2009 \\
\hline
\end{tabular}

Tarif tersebut merupakan tarif tertinggi atau maksimal yang dapat ditetapkan oleh Pemerintah Daerah Kabupaten/Kota dalam melakukan pemugutan pajak di wilayah masing-masing.

\subsection{Retribusi Daerah}

\section{Definisi Retribusi Daerah}

Menurut Marihot (2010:6) retribusi daerah adalah pungutan daerah sebagai pembayaran atas jasa atau pemberian izin tertentu yang khusus disediakan dan atau diberikan oleh pemerintah daerah untuk kepentingan orang pribadi atau badan.

Menurut Munawir dalam Adisasmita (2011:85) retribusi merupakan iuran kepada pemerintah yang dapat dipaksakan dan jasa balik secara langsung dapat ditunjuk. Paksaan ini bersifat ekonomis karena siapa saja yang tidak merasakan jasa balik dari pemerintah dia tidak akan dikenakan iuran itu.

Jadi retribusi daerah merupakan pembayaran atas jasa yang telah diberikan oleh badan kepada masyarakat yang telah menggunakan jasa yang disediakan oleh pemerintah.

\section{Jenis Retribusi Daerah}

Menurut Undang-Undang Nomor 28
Tahun 2009 Tentang Pajak Daerah dan Retribusi Daerah, Pasal 1 ayat 66, 67, 68 Retribusi Daerah digolongkan menjadi tiga bagian yaitu:

a. Retribusi Jasa Umum

b. Retribusi Jasa Usaha

c. Retribusi Perizinan Tertentu

\section{Subjek Retribusi Daerah}

a. Subjek retribusi jasa umum adalah orang pribadi atau badan yang menggunakan/menikmati pelayanan jasa umum yang bersangkutan.

b. Subjek retribusi jasa usaha adalah orang pribadi atau badan yang menggunakan/menikmati pelayanan jasa yang bersangkutan. Sedangkan yang menjadi wajib

c. Subjek retribusi perizinan tertentu adalah orang pribadi atau badan yang memperoleh izin tertentu dari pemerintah daerah.

\section{Tarif Retribusi Daerah}

Menurut Marihot (2010:639) tarif retribusi adalah nilai rupiah atau persentase yang ditetapkan untuk menghitung besarnya retribusi daerah yang terutang. Tarif retribusi dapat ditentukan seragam atau bervariasi menurut golongan sesuai dengan prinsip dan sasaran penetapan tarif retribusi misal:

a. Retribusi Tempat Rekreasi antara anak dan dewasa

b. Retribusi Parkir antara sepeda motor dan mobil

c. Retribusi Pasar antara kios dan los

d. Retribusi Sampah antara rumah tangga dan industri

Oleh karena itu tarif retribusi ditinjau kembali secara berkala dengan memperhatikan prinsip dan sasaran penetapan tarif retribusi, dimaksudkan untuk mengantisipasi perkembangan perekonomian daerah berkaitan dengan objek retribusi yang bersangkutan. Dalam Undang-Undang Nomor 28 Tahun 2009 Pasal 155 ditetapkan bahwa tarif retribusi ditinjau paling lama tiga 
tahun sekali.

\subsection{Belanja Modal}

\section{Definisi Belanja Modal}

Menurut Abdul Halim (2008:4-5) dalam virgin gabriel dkk (2016) belanja modal adalah investasi yang berupa pengadaan atau pembelian aset yang bermanfaat lebih dari 12 bulan dan aset tersebut digunakan dalam kegiatan pemerintahan yang bermanfaat secara ekonomis, sosial, dan manfaat lainnya sehingga dapat meningkatkan kemampuan pemerintah dalam melayani masyarakat. Aset tetap merupakan prasyarat utama dalam memberikan pelayanan publik oleh pemerintah daerah. Untuk menambah aset tetap, pemerintah daerah mengalokasikan dalam bentuk belanja modal dalam APBD. Alokasi belanja modal ini didasarkan pada kebutuhan daerah akan sarana dan prasarana, baik untuk kelancaran dalam pelaksanaan tugas pemerintahan maupun untuk fasilitas publik. Biasanya setiap tahun diadakan pengadaan aset tetap oleh pemerintah sesuai prioritas anggaran dan pelayanan publik yang memberikan dampak jangka panjang secara finansial.

Menurut Peraturan Menteri Keuangan Nomor 127 / PMK, 02/ 2015 Belanja Modal adalah pengeluaran untuk pembayaran perolehan aset tetap dan/atau aset lainnya untuk menambah nilai aset tetap dan/atau aset lainnya yang memberi manfaat lebih dari satu periode akuntansi dan melebihi batas minimal yang kapitalis aset tetap/aset lainnya yang ditetapkan pemerintah.

Aset tetap/aset lainnya tersebut dipergunakan atau dimaksudkan untuk dipergunakan untuk operasional kegiatan suatu Satker atau dipergunakan oleh masyarakat/publik, tercatat sebagai aset kementerian negara/lembaga terkait dan bukan dimaksudkan untuk dijualkan/diserahkan kepada masyarakat/pemda. Dalam pembukuan nilai perolehan aset dihitung semua pendanaan yang dibutuhkan hingga aset tersebut tersedia dan siap untuk digunakan.

Kriteria kapitalis dalam pengadaan/pemeliharaan barang/aset merupakan suatu tahap validasi untuk penetapa belanja modal atau bukan dan merupakan syarat wajib dalam penetapan kapitalis atau pengadaan barang/asset

a. Pengeluaran anggaran belanja tersebut mengakibatkan bertambahnya aset dan/atau bertambahnya masa manfaat/umur ekonomis aset berkenaan. Pengeluaran anggaran belanja tersebut mengakibatkan bertambahnya kapasitas, peningkatan, standar kinerja, atau volume aset

b. Memenuhi nilai minimum kapitalisasi sesuai dengan Peraturan Kementerian Keuangan yang mengatur penatausahaan barang milik negara

c. Pengadaan barang tersebut tidak dimaksudkan untuk diserahkan/dipasarkan kepada masyarakat/Pemda/Entitas lain diluar Pemerintah Pusat

\section{Jenis Klasifikasi Belanja Modal}

Menurut Peraturan Menteri Keuangan Nomor 127/ PMK, 02/ 2015 klasifikasi Belanja Modal ada 6 jenis Belanja Modal:

a. Belanja Modal Tanah

b. Belanja Modal Peralatan dan Mesin

c. Belanja Modal Gedung dan Bangunan

d. Belanja Modal Jalan, Irigasi, dan Jaringan

e. Belanja modal lainnya

\section{Faktor-Faktor Yang Mempengaruhi Belanja Modal}

Belanja Modal adalah pengeluaran untuk pembayaran perolehan aset tetap dan/atau aset lainnya untuk menambah nilai aset tetap dan/atau aset lainnya yang memberi manfaat lebih dari satu periode akuntansi dari satu periode akuntansi. Sesuai 
dengan pemendagri Nomor 33 tahun 2019 bahwa Belanja Modal merupakan klasifikasi dari belanja daerah. Secara spesifik sumber pendanaan Belanja Modal. Namun seluruh jenis sumber-sumber penerimaan daerah dapat dialokasikan untuk mendanai belanja daerah diantaranya Belanja Modal. Menurut Undang-Undang Nomor 33 Tahun 2004 Sumber Pendapatan daerah dibagi menjadi 3:

a. Pendapatan Asli Daerah yaitu Pajak Daerah, Retribusi Daerah, Hasil Kekayaan Daerah yang dipisahkan, dan Lain-Lain PAD yang sah.

b. Dana Perimbangan yaitu Dana Bagi Hasil (DBH), Dana Alokasi Umum (DAU), dan Dana Bagi Hasil (DBH).

c. Lain-Lain Pendapatan yaitu Hasil Penjualan Kekayaan Yang Tidak Dipisahkan, Jasa Giro, Pendapatan Bunga, Keuntungan selisih Nilai Tukar Rupiah Dengan Mata Uang Asing, dan Komisi atau Potongan ataupun bentuk lain sebagai akibat dari penjualan/pengadaan barang dan / jasa oleh Daerah.

\subsection{Hipotesis}

Salah satu sumber pendapatan daerah adalah pendapatan asli daerah (PAD), dalam komponen PAD, Pajak Daerah mempunyai kontribusi dalam memberikan pendapatan bagi daerah. Pemerintah daerah mempunyai wewenang untuk mengalokasikan pendapatannya dalam sektor belanja modal

Ho = Pajak Daerah secara parsial tidak berpengaruh terhadap Belanja Modal Pada Pemerintahan Daerah Kota Lubuklinggau.

H1 = Pajak Daerah secara parsial berpengaruh terhadap Belanja Modal Pada Pemerintahan Daerah Kota Lubuklinggau.

\section{METODOLOGI PENELITIAN}

\subsection{Jenis Penelitian}

Jenis penelitian yang digunakan penulis yaitu penelitian asosiatif karena pada penelitian ini dilakukan untuk mengetahui pengaruh antara dua variabel atau lebih,dengan penelitian ini maka akan dapat dibangun suatu teori yang dapat berfungsi untuk menjelaskan suatu fonomena.

\subsection{Lokasi Penelitian}

Penelitian ini dilakukan pada Pemerintahan Kota Lubuklinggau dengan menggunakan laporan keuangan Pemerintahan Kota Lubuklinggau pada periode 2009-2018 yang dapat dilihat di Laporan Realisasi Anggaran Kota Lubuklinggau.

\subsection{Analisis Data dan Teknik Analisis}

Dalam penelitian ini penulis menggunakan metode analisis kuantitatif dengan teknik analisis statistiak deskriptif. Hipotesis adalah dugaan terhadap ada tidaknya hubungan secara signifikan antara dua variabel atau lebih.

\section{Analisis Regresi Linier Berganda}

Dalam penelitian ini analisis regresi linier berganda digunakan untuk membuktikan sejauh mana hubungan pajak daerah, retribusi daerah dan belanja modal dengan Persamaan untuk analisis regresi liner berganda yaitu:

$$
\mathrm{Y}=\mathrm{a}+\mathrm{b} 1 \mathrm{X} 1+\mathrm{b} 2 \mathrm{X} 2
$$

Keterangan :

$$
\begin{array}{ll}
\mathrm{Y} & =\text { Variabel Dependen } \\
\mathrm{a} & =\text { Konstanta } \\
\mathrm{X} 1 & =\text { Variabel Independen Pertama } \\
\mathrm{X} 2 & =\text { Variabel Independen Kedua } \\
\mathrm{b} 1 & =\text { Koefesien Regresi X1 } \\
\mathrm{b} 2 & =\text { Koefesien Regresi X2 }
\end{array}
$$

\section{a. Uji Asumsi Klasik}

Terdapat beberapa asumsi yang harus dipenuhi terlebih dahulu sebelum menggunakan regresi linier berganda sebagai alat menganalisis pengaruh variabel-variabel yang diteliti, pengujian asumsi klasik yang digunakan yaitu: 


\section{b. Uji Normalitas}

Dengan dasar pengambilan keputusan untuk metode Uji One Sample Kolmogrov-smirnov:

1) Jika nilai Asymp. Sig. (2-tailed) $>0,05$ maka data terdistribusi secara normal

2) Jika nilai Asymp. Sig. (2-tailed) $<0,05$ maka data tidak terdistribusi secara normal

\section{c. Uji Multikolinearitas}

Pada penelitian ini penulis menggunakan uji asumsi multikolinaritas dengan melihat nilai VIF dan nilai tolerance untuk melihat apakah penelitian ini terjadi multikolinearitas atau tidak. Dengan dasar pengambilan keputusan yaitu:

1) Jika nilai tolerance $>0,1$ dan nilai VIF < 10 maka dikatakan tidak terjadi multikolinearitas.

2) Jika nilai tolerance $\langle 0,1$ dan nilai VIF $>$ 10 maka dikatakan terjadi multikolinearitas.

\section{d. Uji Heteroskedastitas}

Uji yang digunakan adalah uji gletsjer dengan meregres nilai absolut residual sebagai variabel dependen, jika variabel independen secara signifikan mempengaruhi absolut residual maka ada indikasi heteroskedasitas dan sebaliknya jika variabel independen tidak mempengaruhui absolut residual maka tidak ada indikasi heteroskedasitas dengan dasar mengambil keputusan:

1) Jika nilai signifikansi antara variabel independen dengan absolut residual > 0,05 maka tidak terjadi heteroskedasitas.

2) Jika nilai signifikansi antara variabel independen dengan absolut residual < 0,05 maka terjadi heteroskedasitas

\section{e. Uji Autokorelasi}

Metode pengujian yang sering digunakan adalah dengan uji Durbin-Watson (Uji DW) dengan kriteria sebagai berikut:
1) Bila nilai $\mathrm{D}-\mathrm{W}$ dibawah -2 berarti autokorelasi positif.

2) Bila nilai $\mathrm{D}-\mathrm{W}$ diantara -2 sampai +2 berarti tidak ada autokorelasi.

3) Bila nilai D-W diatas +2 berarti autokorelasi negatif.

\section{Pengujian Hipotesis}

a. Uji t (Uji Parsial)

Uji t (t-test) digunakan untuk menguji koefesien korelasi secara parsial. Hasil pengujian ini selanjutnya akan dibandingkan dengan $t$ tabel dengan menggunakan tingkat kesalahan 5\% atau 0,05 . Kriteria yang digunakan adalah sebagai berikut:

1. Ho diterima jika nilai $t_{\text {hitung }} \leq t_{\text {tabel }}$

2. Ho ditolak jika nilai $t_{\text {hitung }} \geq t_{\text {tabel }}$

\section{b. Uji F (Uji Simultan)}

Uji $F$ adalah pengujian terhadap koefesien korelasi secara simultan. pengujian $\mathrm{F}$ hitung ini kemudian akan dibandingkan dengan Ftabel dengan Kriteria:

1) H0 diterima jika nilai $f_{\text {hitung }} \leq f_{\text {tabel }}$

2) H0 ditolak jika nilai $f_{\text {hitung }} \geq f_{\text {tabel }}$

\section{c. Koefesien Determinasi}

Koefesien ini disebut koefesien penentu karena varians yang terjadi pada variabel dependen dapat dijelaskan melalui varians yang terjadi pada variabel independen, nilai koefesien determinasi adalah antara 0 dan 1, nilai R2 yang kecil berarti kemampuan variabel independen dalam menjelaskan variabel dependen sangat terbatas.

Dari keseluruhan metode yang digunakan dalam penelitian ini, penulis akan menggunakan alat bantu berupa aplikasi SPSS 20 untuk mengelola dan menganalisis data.

\section{HASIL DAN PEMBAHASAN}

4.1 Hasil Penelitian

Kota Lubuklinggau telah menerapkan Undang-Undang Nomor 28 
Tahun 2009 tersebut pada tahun 2010 baru menerapkan 10 jenis pajak daerah dan mulai menerapkan 11 jenis pajak daerah tersebut mulai 2012. Adapun komponen pajak daerah Kota Lubuklinggau sebagai berikut :

1. Pajak Hotel

2. Pajak Restoran

3. Pajak Hiburan

4. Pajak Reklame

5. Pajak Penerangan Jalan

6. Pajak Mineral Bukan Logam dan Batuan

7. Pajak Parkir Pajak Air Tanah

8. Pajak Sarang Burung Walet

9. Pajak Bumi Bangunan Perdesaan dan Perkotaan

10. Bea Perolehan Hak atas Tanah dan Bagunan

Adapun data realisasi penerimaan pajak daerah kota lubuklinggau pada tahun 2009 sampai 2018 sebagai berikut :

\section{TABEL 3}

REALISASI PENERIMAAN PAJAK DAERAH KOTA LUBUKLINGGAU TAHUN 2009-2018

\begin{tabular}{|c|c|c|c|c|}
\hline No & Tahun & $\begin{array}{c}\text { Pajak } \\
\text { Daerah }\end{array}$ & $(\%)$ & Keterangan \\
\hline 1 & 2008 & 4.649 .731 & - & - \\
\hline 2 & 2009 & 5.663 .341 & 17,90 & Meningkat \\
\hline 3 & 2010 & 6.112 .768 & 7.35 & Meningkat \\
\hline 4 & 2011 & 12.127 .425 & 49,59 & Meningkat \\
\hline 5 & 2012 & 13.188 .032 & 8,04 & Meningkat \\
\hline 6 & 2013 & 17.626 .306 & 25,17 & Meningkat \\
\hline 7 & 2014 & 17.858 .006 & 1,29 & Meningkat \\
\hline 8 & 2015 & 19.666 .150 & 9,19 & Meningkat \\
\hline 9 & 2016 & 22.254 .695 & 11,63 & Meningkat \\
\hline 10 & 2017 & 29.121 .881 & 23,58 & Meningkat \\
\hline 11 & 2018 & 38.458 .612 & 24,27 & Meningkat \\
\hline
\end{tabular}

Sumber : data diolah

Tabel 3 nenjelaskan bahwa pajak daerah Kota Lubuklinggau selalu mengalami peningkatan pada tiap tahunnya, persentase pajak daerah tertinggi terjadi pada tahun 2018 yaitu sebesar $24.27 \%$, hal ini terkait penerimaan pajak daerah sebesar $\mathrm{Rp}$ 38.458.611.

Kota Lubuklinggau telah menerapkan Undang-Undang Nomor 28 Tahun 2009 dalam menetapkan jenis retribusi daerah. Adapun komponen retribusi daerah Kota Lubuklinggau sebagai berikut :

1. Retribusi Jasa Umum

2. Retribusi Jasa Usaha terdiri dari:

3. Retribusi Izin tertentu terdiri dari :

Adapun data realisasi penerimaan retribusi daerah Kota Lubuklinggau pada tahun 2009-2018 disajikan dalam tabel sebagai berikut :

TABEL 4

REALISASI PENERIMAAN RETRIBUSI DAERAH KOTA LUBUKLINGGAU TAHUN 2009-2018

\begin{tabular}{|c|c|c|c|c|}
\hline \multicolumn{5}{|c|}{ (dalam Ribuan Rupiah) } \\
\hline No & Tahun & $\begin{array}{c}\text { Retribusi } \\
\text { Daerah }\end{array}$ & $(\%)$ & Keterangan \\
\hline 1 & 2008 & 3.758 .503 & - & - \\
\hline 2 & 2009 & 3.571 .544 & $(5,23)$ & Menurun \\
\hline 3 & 2010 & 4.563 .750 & 21,74 & Menurun \\
\hline 4 & 2011 & 4.575 .857 & 0,26 & Meningkat \\
\hline 5 & 2012 & 4.112 .124 & $(11,27)$ & Menurun \\
\hline 6 & 2013 & 4.948 .387 & 17,50 & Meningkat \\
\hline 7 & 2014 & 6.284 .358 & 20,80 & Meningkat \\
\hline 8 & 2015 & 4.420 .850 & $(42,15)$ & Menurun \\
\hline 9 & 2016 & 4.472 .108 & 1,14 & Meningkat \\
\hline 10 & 2017 & 6.040 .821 & 25,96 & Meningkat \\
\hline 11 & 2018 & 8.646 .857 & 30,13 & Meningkat \\
\hline
\end{tabular}

Sumber : data diolah

Tabel 4 menjelaskan bahwa penerimaan retribusi daerah mengalami keadaan fluktuatif tiap tahun nya. Retribusi daerah mengalami penurunan tertinggi pada tahun 2015 yaitu $42,15 \%$ dengan penerimaan sebesar Rp 4.420.848 dan kenaikan tertinggi pada tahun 2018 yaitu $30,31 \%$ dengan penerimaan sebesar Rp 8.646.857.

Sesuai Peraturan Menteri Keuangan 
Nomor 127/ PMK, 02/ 2015 tentang klasifikasi belanja modal, Kota Lubuklinggau menetapkan jenis belanja modal menjadi 5 jenis yaitu:

1. Belanja Tanah

2. Belanja Peralatan dan Mesin

3. Belanja Bagunan dan Gedung

4. Belanja Jalan,irigasi dan Jaringan

5. Belanja Aset Tetap Lainnya

Adapun data belanja modal Kota Lubuklinggau pada tahun 2009-2018 disajikan dalam tabel sebagai berikut :

\section{TABEL 5}

BELANJA MODAL PEMERINTAH KOTA LUBUKLINGAU TAHUN 2009-2018

(dalam Ribuan Rupiah)

\begin{tabular}{|c|c|c|c|c|}
\hline No & Tahun & $\begin{array}{c}\text { Belanja } \\
\text { Modal }\end{array}$ & $\%$ & Keterangan \\
\hline 1 & 2008 & 185.455 .515 & - & - \\
\hline 2 & 2009 & 146.150 .506 & $(26,89)$ & Menurun \\
\hline 3 & 2010 & 142.818 .340 & $(2,33)$ & Menurun \\
\hline 4 & 2011 & 177.574 .126 & 19,57 & Meningkat \\
\hline 5 & 2012 & 162.346 .771 & $(9,37)$ & Menurun \\
\hline 6 & 2013 & 282.058 .335 & 42,44 & Meningkat \\
\hline 7 & 2014 & 295.111 .299 & 4,42 & Meningkat \\
\hline 8 & 2015 & 215.943 .462 & $(36.66)$ & Menurun \\
\hline 9 & 2016 & 205.417 .240 & $(5,12)$ & Menurun \\
\hline 10 & 2017 & 237.003 .593 & 13,32 & Meningkat \\
\hline 11 & 2018 & 209.920 .268 & $(12.90)$ & Menurun \\
\hline
\end{tabular}

Sumber : data diolah

Tabel 5 menjelaskan bahwa belanja modal kota Lubuklinggau dari tahun ke tahun mengalami keadaan fluktuatif tiap tahun nya, belanja modal mengalami penurunan tertinggi pada tahun 2016 yaitu $36,66 \%$, dengan nilai belanja $\mathrm{Rp}$ 215.943.462 dan belanja modal mengalami kenanikan tertinggi pada Kota Lubuklinggau adalah pada tahun 2013 yaitu $42,44 \%$ dengan nilai belanja $\mathrm{Rp} 282.058 .335$.

\subsection{Pembahasan}

1. Uji Asumsi Klasik

a. Uji Normalitas Data

TABEL 6

HASIL UJI KOLMOGROV-SMIRNOV One-Sample Kolmogorov-Smirnov Test

\begin{tabular}{|l|rr|}
\hline & \multicolumn{2}{|c|}{$\begin{array}{c}\text { Unstandardized } \\
\text { Residual }\end{array}$} \\
\hline Asymp. Sig. (2-tailed) & \multicolumn{2}{|c|}{.772} \\
\hline
\end{tabular}

a. Test distribution is Normal.

b. Calculated from data

Sumber : Hasil Olahan SPSS 20

Berdasarkan tabel 6 diatas, dapat diketahui bahwa jumlah data yang dimaksukkan dalam pengujian ini adalah 10 data. Nilai Kolmogrov-Smirnov sebesar 0,667 dan nilai signifikannya (Asymp. Sig. (2-tailed) sebesar 0,772 >0,05 yang berarti data residual berdistribusi normal.

\section{b. Uji Multikolinearitas}

TABEL 7

HASIL UJI MULTIKOLINEARITAS

\begin{tabular}{|c|c|c|c|}
\hline \multirow{2}{*}{\multicolumn{2}{|c|}{ Model }} & \multicolumn{2}{|c|}{ Collinearity Statistics } \\
\hline & & Tolerance & VIF \\
\hline \multirow{3}{*}{1} & (Constant) & & \\
\hline & Pajak Daerah & .299 & 3.350 \\
\hline & $\begin{array}{l}\text { Rertibusi } \\
\text { Daerah }\end{array}$ & .299 & 3.350 \\
\hline
\end{tabular}

a. Dependent Variable: Belanja Modal

Sumber : Hasil Olahan SPSS 20

Berdasarkan tabel 7 diatas menunjukan bahwa variabel independen tidak terjadi multikolinearitas dimana nilai Tolarance Pajak Daerah dan Retribusi Daerah adalah 0,299 dan Nilai VIF Pajak Daerah dan Retribusi Daerah adalah 3.350, masing-masing nilai variabel tersebut Tolarance $>0,1$ dan VIF $<10$. 
c. Uji Heteroskedastistas

TABEL 8

HASII UJI HETEROSKEDASITAS

\begin{tabular}{|rl|r|r|}
\hline \multicolumn{2}{|l|}{ Model } & \multicolumn{1}{c|}{$\mathrm{t}$} & Sig. \\
& & & \\
\hline \multirow{4}{*}{1} & (Constant) & -1.165 & .282 \\
& Pajak Daerah & -2.176 & .066 \\
& Rertibusi Daerah & 2.600 & .055 \\
\hline
\end{tabular}

a. Dependent Variable: Abs_RES

Sumber: Hasil Olahan SPSS 20

Tabel 8 diatas menjelaskan bahwa nilai signifikansi pada Variabel Pajak Daerah adalah 0,66 dan Retribusi Daerah 0,55, dimana nilai kedua variabel independen lebih dari 0,05 sehingga dapat disimpulkan tak terjadi gejala hetrokedastistas pada model regresi.

\section{d. Uji Autokorelasi}

TABEL 9

HASIL UJI AUTOKORELASI

\begin{tabular}{|l|r|}
\hline Model & \multicolumn{2}{|c|}{ Durbin-Watson } \\
\hline 1 & 1.101 \\
\hline
\end{tabular}

a. Predictors: (Constant), Rertibusi Daerah, Pajak Daerah

b. Dependent Variable: Belanja Modal

Sumber: Hasil Olahan SPSS 20

Hasil autokorelasi dengan kriteria sebagai berikut:

1. Bila nilai $\mathrm{D}-\mathrm{W}$ dibawah -2 berarti autokorelasi positif.

2. Bila nilai $\mathrm{D}-\mathrm{W}$ diantara -2 sampai +2 berarti tidak ada autokorelasi.

3. Bila nilai $\mathrm{D}-\mathrm{W}$ diatas +2 berarti autokorelasi negatif.

Pada tabel 9 nilai DW adalah 1.101 berarti nilai DW tersebut berada diantara -2 sampai +2 yang berarti tidak terjadi autokorelasi pada regresi ini.
2. Analisis Regresi Linier Berganda

TABEL 10

PERSAMAAN REGRESI LINIER BERGANDA

\begin{tabular}{|c|c|c|}
\hline Model & $\mathrm{t}$ & Sig. \\
\hline (Constant) & 1.980 & .088 \\
\hline Pajak Daerah & .542 & .605 \\
\hline $\begin{array}{l}\text { Rertibusi } \\
\text { Daerah }\end{array}$ & .283 & .785 \\
\hline
\end{tabular}

a. Dependent Variable: Belanja Modal Sumber : Hasil Olahan SPSS 20

Berdasarkan hasil analisis regresi diatas diperoleh persamaan regresi linier berganda pada penelitian ini yaitu :

$$
Y=144357995,684+1,703 X_{1}+6,136 X_{2}
$$

Analisis dari persamaan regresi diatas yaitu :

1) Nilai konstanta 144357995,684 menjelaskan bahwa jika variabel Pajak Daerah dan Retribusi Daerah masingmasing bernilai 0 (nol), maka Belanja Modal akan ada sebesar Rp 144.357.995,684

2) Nilai koefesien variabel pajak daerah sebesar 1,720 menunjukan bahwa arah hubungan positif antara Pajak Daerah dengan Belanja Modal, setiap kenaikan Pajak Daerah Rp 1, maka Belanja Modal akan bertambah sebesar Rp 1,703 dengan asumsi variabel $\mathrm{X} 2$ dianggap Ceteris Paribus.

3) Nilai koefesien variabel Retribusi Daerah sebesar 6,149 menunjukan bahwa arah hubungan positif antara Retribusi Daerah dengan Belanja Modal, setiap kenaikan Retribusi Daerah Rp 1, maka belanja Modal akan bertambah sebesar Rp 6,136 dengan asumsi variabel $\mathrm{X} 1$ dianggap Ceteris Paribus. 
a. Uji Hipotesis

1) Uji t (Uji Parsial)

TABEL 11

HASIL UJI T (PARSIAL)

\begin{tabular}{|c|c|c|c|}
\hline Model & & $\mathrm{t}$ & Sig. \\
\hline \multirow{3}{*}{1} & (Constant) & 1.980 & .088 \\
\hline & Pajak Daerah & .542 & .605 \\
\hline & Rertibusi Daerah & .283 & .785 \\
\hline
\end{tabular}

a. Dependent Variable: Belanja Modal

Sumber : Hasil olahan SPSS 20

Hasil uji t dan dibandingkan t tabel dengan menggunakan tingkat kesalahan 0,05 . Kriteria yang digunakan adalah sebagai berikut:

1. Ho diterima jika nilai $t_{\text {hitung }} \leq t_{\text {tabel }}$

2. Ho ditolak jika nilai $t_{\text {hitung }} \geq t_{\text {tabel }}$

Berdasarkan nilai uji $t$ yang diperoleh maka, secara parsial pengaruh variabel independent terhadap variabel dependent adalah sebagai berikut:
1) Pengaruh Pajak Daerah terhadap Belanja Modal

Dari analisis Pajak Daerah diperoleh nilai $\mathrm{t}$ hitung $<\mathrm{t}$ tabel yaitu $0,542<2,364$ dengan nilai signifikansi sebesar $0,605>$ 0,025 yang berarti $\mathrm{H}_{0}$ diterima dan $\mathrm{H}_{1}$ ditolak, dalam hal ini berarti tidak terdapat pengaruh antara Pajak Daerah terhadap Belanja Modal dengan asumsi variabel lainnya konstan.

2) Pengaruh Retribusi Daerah terhadap Belanja Modal

Dari analisis Retribusi Daerah diperoleh nilai $\mathrm{t}$ hitung $<\mathrm{t}$ tabel yaitu $0,283<$ 2,364 dengan nilai signifikansi sebesar 0,785 $>0,025$ yang berarti $\mathrm{H}_{0}$ diterima dan $\mathrm{H}_{1}$ ditolak, dalam hal ini berarti tidak terdapat pengaruh antara Retribusi Daerah terhadap Belanja Modal dengan asumsi variabel lainnya konstan.

\section{Uji F (Uji Simultan)}

TABEL 12

HASIL UJI F (SIMULTAN)

\begin{tabular}{|ll|c|c|}
\hline Model & & F & Sig. \\
\hline 1 & $\begin{array}{l}\text { Regression } \\
\text { Residual } \\
\text { Total }\end{array}$ & 1.057 & $.397^{\mathrm{b}}$ \\
\hline
\end{tabular}

a. Dependent Variable: Belanja Modal

b. Predictors: (Constant), Rertibusi Daerah, Pajak Daerah

Sumber: Hasil Olahan SPSS 20

\section{Hasil Uji F dengan Kriteria:}

1. Ho diterima jika nilai $f_{\text {hitung }} \leq f_{\text {tabel }}$

2. Ho ditolak jika nilai $f_{\text {hitung }} \geq f_{\text {tabel }}$

Berdasarkan hasil uji $F$ diatas diperoleh F hitung < F tabel yaitu 1.057 < 4.74 dengan nilai signifikansi sebesar 0,397 $>0,05$, sehingga dapat disimpulkan bahwa H0 diterima dan H1 ditolak yang berarti bahwa tidak terdapat pengaruh yang signifikan antara Pajak Daerah dan Retribusi Daerah terhadap Belanja Modal.

\section{Koefesien Determinasi}

TABEL 13

KOEFESIEN DETERMINASI

\begin{tabular}{|l|r|r|}
\hline Model & \multicolumn{1}{|c|}{ R } & \multicolumn{1}{c|}{ R Square } \\
\hline 1 & $.482^{\mathrm{a}}$ & .232 \\
\hline
\end{tabular}

a. Predictors: (Constant), Rertibusi Daerah, Pajak Daerah

Sumber : Hasil Olahan SPSS 20

Berdasarkan tabel diatas diketahui bahwa nilai dari koefesien determinasi (R2) pada penelitian ini adalah sebesar 0,232 atau 23.2\%. Dengan demikian kemampuan variabel independen yang terdiri dari Pajak Daerah dan Retribusi Daerah dapat menjelaskan variabel Belanja Modal sebesar $23 \%$ sedangkan sisanya sebesar $76,8 \%$ dipengaruhi oleh pendapatan daerah lainnya. 


\section{KESIMPULAN}

Pada penelitian ini bertujuan untuk mengetahui pengaruh pajak daerah dan retribusi daerah terhadap belanja modal pada pemerintah daerah lubuklinggau pada tahun 2009-2018. Berdasarkan hasil uji regresi linier berganda diperoleh persamaan regresi. $\mathrm{Y}=144357995,684+1,703 \mathrm{X}_{1}+6,136 \mathrm{X}_{2}$

1. Berdasarkan hasil uji $t$ secara parsial masing-masing variabel terhadap Belanja Modal adalah sebagai berikut:

a. Dari analisis Pajak Daerah diperoleh nilai $\mathrm{t}_{\text {hitung }}<\mathrm{t}$ tabel yaitu $0,542<2,364$ dengan nilai signifikansi sebesar 0,605 $>0,025$ yang berarti $\mathrm{H}_{\mathrm{o}}$ diterima dan $\mathrm{H}_{1}$ ditolak, dalam hal ini berarti tidak terdapat pengaruh antara Pajak Daerah terhadap Belanja Modal.

b. Dari analisis Retribusi Daerah diperoleh nilai $\mathrm{t}$ hitung $<\mathrm{t}$ tabel yaitu $0,283<2,364$ dengan nilai signifikansi sebesar $0,785>0,025$ yang berarti $\mathrm{H}_{\mathrm{o}}$ diterima dan $\mathrm{H}_{1}$ ditolak, dalam hal ini berarti tidak terdapat pengaruh antara Retribusi Daerah terhadap Belanja Modal

2. Berdasarkan hasil uji $F$ diatas diperoleh $F$ hitung < F tabel yaitu $1.057<4.74$ dengan nilai signifikansi sebesar 0,397 > 0,05 , sehingga dapat disimpulkan bahwa Ho diterima dan $\mathrm{H} 1$ ditolak yang berarti bahwa tidak terdapat pengaruh yang signifikan antara Pajak Daerah dan Retribusi Daerah terhadap Belanja Modal.

3. Berdasarkan hasil uji koefesien determinasi diketahui bahwa nilai dari koefesien determinasi (R2) pada penelitian ini adalah sebesar $0,23,2$ atau 23\%. Dengan demikian kemampuan variabel independen yang terdiri dari Pajak Daerah dan Retribusi Daerah dapat menjelaskan variabel dependen Belanja Modal sebesar 23,2\% sedangkan sisanya sebesar $76,8 \%$ dipengaruhi oleh variabel lain seperti Dana Perimbangan dan pendapatan daerah lainnya yang tidak dijelaskan dalam penelitian ini.

\section{SARAN}

Pemerintah Kota Lubuklinggau dapat meningkatkan penerimaan di sektor pajak daerah dan retribusi daerah dengan lebih mengoptimalkan pengenaan objek pajak daerah dan retribusi daerah dengan melakukan sistem pemeriksaan secara dadakan atau berkala dan juga melakukan pengidentifikasian pembayar pajak baru dan pada belanja modal dapat difokuskan pada sektor-sektor yang mampu mendorong peningkatan ekonomi dan kemandirian masyarakat secara berkelanjutan dengan cara pembangunan infrastruktur dan di sektor produktif yang mampu mendorong ekonomi sehingga nantinya penerimaan daerah dalam sektor tersebut dapat ditingkatkan

Untuk penelitian selanjutnya dapat menambahkan variabel independen lain seperti pendapatan transfer seperti Dana Alokasi Umum (DAU), Dana Alokasi Khusus (DAK) dan Dana Bagi Hasil (DBH) untuk memperoleh hasil yang lebih relavan.

\section{DAFTAR PUSTAKA}

[1] Kesuma, Krisna Arta Anggar dan Ni Gst Putu Wirawati. Analisis Pengaruh Penerimaan Pajak Daerah dan Retribusi Daerah Terhadap Peningkatan PAD Sekabupaten/Kota di Provinsi Bali. E- Journal Akuntansi Universitas Undayana. (http://garuda.ristekdikti.go.id/journal /131459 diakses 10 Januari 2020)

[2] Laksono, Bagus Bowo 2014. Pengaruh Pajak Daerah, Retribusi Daerah, DAU, dan DAK terhadap Belanja Daerah. Joural Unnes. (https://journal.unnes.ac.id/sju/index. php/aaj/article/view/4207 diakses 10 $\underline{\text { Januari 2020) }}$

[3] Priyastama Romie. 2017. Buku Sakti Kuasai SPSS. Bantul : Start Up. 
[4] Peraturan Menreri dalam Negeri Nomor 13 tahun 2006 tentang pengelolaan keuangan daerah. Jakarta: Dapartemen Dalam Negeri Republik Indonesia

[5] Putusan Menteri Keuangan Republik Indonesia Tentang Klasifikasi Anggaran, Jakarta: Menteri Keuangan Republik Indonesia.

[6] Runtu, Virgin Gabriel, Een Novritha Walewangko dan Krest D Tolongsang. Pengaruh Pajak dan Retribusi terhadap Belanja Modal Kota Monado (Periode 2005-2015). E-Journal Unsrat. (https://ejournal.unsrat.ac.id/index.ph $\mathrm{p} / \mathrm{jbie} / \mathrm{article} / \mathrm{view} / 13570$ diakses 10 Januari 2020).

[7] Siahaan, Marihot Pahala. 2010. Pajak Daerah dan Retribusi Daerah Berdasarkan Undang-Undang Nomor 28 Tahun 2009. Jakarta: PT RajaGrafindo Persada.

[8] Sugiyono, 2013. Metode penelitian administrasi dengan metode $R \& D$. Bandung alfabeta.

[9] Sugiyono. 2017. Metode Penelitian Kombinasi (Mixed Methods). Bandung: Alfabeta.

[10] Suyotno, Danang. 2013. Meteodologi Penelitian Akuntansi. Bandung: PT Refika Aditama.

[11] Undang-Undang Republik Indonesia Nomor 28 Tahun 2009 tentang Pajak Daerah dan Retribusi Daerah. Jakarta: Direktorat Jendral Perimbangan Keuangan.

[12] Undang-Undang Republik Indonesia Nomor 33 Tahun 2004 tentang
Perimbangan Keuangan antara

Pemerintah Pusat dan Pemerintah

Daerah. Direktorat Jendral

Perimbangan Keuangan. 